\title{
URGENSI PEMIKIRAN IBNU AL-QAYYIM AL-JAUZIYYAH TENTANG PERUBAHAN HUKUM TERHADAP PERKEMBANGAN SOSIAL HUKUM ISLAM DI LINGKUNGAN PERADILAN AGAMA WILAYAH SULAWESI SELATAN
}

\author{
Hj. Rusdaya Basri \\ Institut Agama Islam Negeri (IAIN) Parepare \\ rusdayabasri@gmail.com
}

\begin{abstract}
This study examines the urgency of Ibn al-Qayyim al-Jauziyyah's thinking about legal changes to the social development of Islamic law in the Religion Court area of South Sulawesi. The thought of Ibn al-Qayyim al-Jauziyyah concerning legal changes to the social development of Islamic law based on changes in time, place, conditions, intentions and customs. Maslahah is the principle to change of legal fatwa based on changes in time, place, circumstances, and customs that apply in a place in accordance with the goals and the benefits desired by the Shari'a. The legal theory of Ibn al-Qayyim al-Jauziyyah in general has been implemented in the ruling or legal stipulation in the Religion Court in the South Sulawesi region. The theory is implicitly used. The judge decides the case with regard to local conditions and conditions.
\end{abstract}

Keywords: Ibn al-Qayyim, al-Jauziyyah, Islamic Law, Social Islamic Law, Amendment to Law.

Abstrak: Penelitian ini mengkaji tentang urgensi pemikiran Ibnu al-Qayyim alJauziyyah tentang perubahan hukum terhadap perkembangan sosial hukum Islam di lingkungan Peradilan Agama wilayah Sulawesi Selatan. Pemikiran Ibnu al- Qayyim al-Jauziyyah tentang perubahan hukum terhadap perkembangan sosial hukum Islam yaitu perubahan dan perbedaan fatwa berdasarkan perubahan waktu, tempat, kondisi dan niat serta adat. Kemaslahatan sebagai asas untuk merubah fatwa hukum menurut perubahan waktu, tempat, keadaan, dan adat kebiasaan yang berlaku di suatu tempat, sesuai dengan tujuan dan kemaslahatan yang dinginkan pembuat syariat. Teori hukum Ibnu al-Qayyim al-Jauziyyah pada umumnya sudah terimplementasikan pada putusan atau penetapan hukum di lingkungan Peradilan Agama wilayah Sulawesi Selatan. Teori tersebut tidak tersurat dipakai, tetapi secara tersirat tetap dipakai. Hakim memutuskan perkara dengan memperhatikan situasi dan kondisi setempat.

Kata Kunci: Ibnu al-Qayyim, al-Jauziyyah, Hukum Islam, Sosial Hukum Islam, Perubahan Hukum.

\section{PENDAHULUAN}

Pemikiran hukum Islam dalam konteks historis memperlihatkan kekuatan yang dinamis dan kreatif 
188 | Diktum: Jurnal Syari'ah dan Hukum, Volume 16, Nomor 2 Desember 2018 : 187 - 207

dalam mengantisipasi setiap perubahan dan persoalan-persoalan baru. Hubungan antara hukum Islam dan perubahan sosial teraktualisasi dalam realitas sejarah perkembangan hukum Islam sejak pembentukan hukum Islam sampai perkembangan terakhir pada zaman modern sekarang ini. Masa pembentukan hukum Islam pada zaman Nabi Muhammad saw., perubahan hukum dikenal dengan istilah nasakh. Misalnya, pada awal kemunculan Islam, keislaman orangorang belum kuat, kebiasaan ziarah kubur dilarang oleh Islam untuk menghindari kemungkinan terjadinya syirik kepada Allah swt. Akan tetapi, pada perkembangannya, ketika keislaman masyarakat menjadi kuat, kebiasaan ziarah kubur itu diperbolehkan sebab kemungkinan tidak terjadi syirik kepada Allah. Ini tergambar dalam hadis Nabi Muhammad saw. yang diriwatkan oleh Muslim.

Pasca era Nabi merupakan masa Sahabat yang memiliki otoritas untuk menetapkan hukum yang bersumber dari al-Qur'an dan hadis. Para Sahabat berijtihad dengan memperhatikan perkembangan sosial yang terjadi dalam kehidupan masyarakat. Misalnya, keputusan 'Umar bin Khattab (w. $23 \mathrm{H}$ ) tentang harta rampasan perang (ganimah), khususnya harta yang tidak bergerak. Setelah 'Umar memperoleh informasi tentang keberhasilan tentara Islam membebaskan Syam, Irak, dan Negeri Khusru (Persia), 'Umar merasa perlu membuat kebijakan kontroversial demi menjaga stabilitas moneter negara yang ketika itu sedang mengalami krisis. ${ }^{2}$ Pandangan 'Umar tentang hukum berubah apabila kondisi sosial berubah. Karakteristik pemikiran yang tersebut diikuti oleh sahabat-sahabat yang lain, misalnya 'Abdullah bin Mas'ud, Zaid bin Sabit dan sahabat lainnya. ${ }^{3}$ Hal yang sama dilakukan oleh khalifah ketiga 'Usman bin Affan dan khalifah keempat "Ali bin Abu Talib dalam menetapkan prinsip barang temuan. ${ }^{4}$

Periode berikutnya, muncul tokoh-tokoh mazhab masing-masing memiliki formulasi kerangka berpikir dan metodologi sesuai dengan 
perkembangan sosial budaya pelaksana kekuasaan kehakiman di masyarakat setempat. Seperti Abu Negara Indonesia selalu mengikuti Hanifah (80 H-150) terkenal dengan dinamika kehidupan masyarakat istihsan, Malik (93 H-179 H) dengan diperlukan kreativitas hakim sebagai maslahah mursalah, dan al-Syafi'i (150-204 H) dengan metode kias. Metode-metode tersebut penerap dan penggali hukum. Secara epistimologi, hakim adalah penemu mempertimbangkan kemaslahatan masyarakat. Apabila kemaslahatan itu mengalami perubahan, konsekuensi hukumnya pun mengalami perubahan pula. Selain itu, Imam Syafi'i terkenal dengan qaul al-qadim dan qaul aljadid $^{5}$ yaitu perubahan fatwanya setelah bermigrasi dari Irak ke Mesir sebab perbedaan kondisi sosiologis yang ditemukan pada kedua negara itu.

Periode imam mazhab berakhir, berikutnya para ulama yang menformulasikan teori-teori hukum, di antaranya adalah Ibnu al-Qayyim alJauziyyah (691-751 H) dengan teorinya monumental tentang teori perubahan sosial yakni tidak dapat dipungkiri terjadinya perubahan hukum sebab perubahan waktu, tempat, keadaan, niat dan adat. ${ }^{6}$

Berkaitan dengan hal tersebut, Pengadilan Agama sebagai salah satu hukum terapan (materi) dalam aneka ragam kasus yang menjadi yurisprudensi. ${ }^{7}$

Pertentangan antara kepastian hukum dan keadilan dalam berbagai kasus hukum sering ditemukan. Putusan pengadilan menyangkut pencurian sandal jepit, pencurian kakao, pencurian semangka yang nilainya rendah, tetapi unsur-unsur delik terbukti. Namun, sanksi pidana yang dijatuhkan oleh hakim mengundang kontroversi di tengahtengah masyarakat. Kalangan masyarakat intelektual menyatakan bahwa hukumannya tidak adil dan bertentangan dengan rasa keadilan masyarakat. Sementara koruptor dan perampok kelas kakap, seperti Anggodo Widjojo dan Gayus Tambunan yang begitu "kuat" dalam berhadapan dengan aparat penegak hukum bebas berkeliaran dan berpesiar 
190 | Diktum: Jurnal Syari'ah dan Hukum, Volume 16, Nomor 2 Desember 2018 : 187 - 207

ke luar negeri.

Kasus-kasus

tersebut

merupakan contoh kecil dari wajah hukum di Indonesia yang menimbulkan keprihatinan berbagai kalangan lapisan masyarakat mengenai keadaan penegakan hukum di Indonesia saat ini yang dinilai tidak mencerminkan keadilan dan tidak berpihak pada masyarakat kecil. Sorotan tajam dalam hal ini adalah aparat penegak hukum yaitu polisi, jaksa, hakim dan advokat yang dipersalahkan sebagai para pihak yang menyebabkan merosotnya kewibawaan hukum. ${ }^{8}$

$$
\text { Tulisan ini berupaya }
$$
menganalisis putusan peradilan agama dengan mengaitkannya dengan teori perubahan hukum Ibnu al-Qayyim alJauziyyah yang menyatakan bahwa perubahan fatwa adalah disebabkan perubahan zaman, tempat, keadaan dan kebiasaan penting diterapkan pada putusan atau penetapan hukum di lingkungan Peradilan Agama wilayah Sulawesi Selatan. Hal ini sejalan dengan Pasal 5 Undang-undang No. 48 Tahun 2009 tentang kekuasaan kehakiman, yang mewajibkan hakim menggali, mengikuti dan memahami nilai-nilai hukum serta rasa keadilan yang hidup dalam masyarakat.

\section{PEMBAHASAN}

\section{A. Aktualisasi Perubahan Hukum Ibnu al-Qayyim dalam} Pandangan Hakim.

Pemikiran Ibnu al-Qayyim alJauziyyah tentang perubahan hukum terhadap perkembangan sosial hukum Islam dituangkan dalam kitabnya 'Ilam al-Muwaqq in 'an Rabbi al-'Alamin, yaitu:

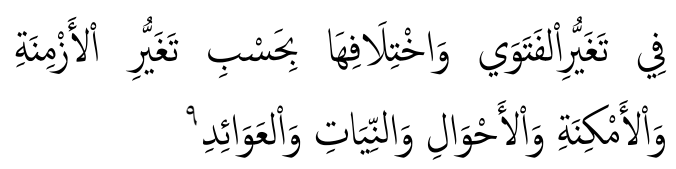

Artinya:

"Perubahan dan perbedaan fatwa berdasarkan perubahan waktu, tempat, kondisi dan niat serta adat".

Inti dari pandangan Ibnu alQayyim al-Jauziyyah tersebut adalah penetapan hukum dikaitkan dengan lima hal yakni al-azmina (situasi zaman), al-amkinah (situasi tempat), al-ahwal (kondisi) al-niyāt (motivasi/ niat), dan al-'awāid (adat-tradisi). Kelima hal tersebut yang menjadi 
sebab (al-illah) dalam perubahan fatwa hukum. Fatwa hukum berubah seiring dengan perubahan situasi zaman, situasi tempat, kondisi, motivasi/niat dan adat tradisi setempat.

Ibnu al-Qayyim menyatakan bahwa syariat ditegakkan demi kemaslahatan para hamba di dunia dan di akhirat kelak. Selanjutnya ditegaskan bahwa sesungguhnya pondasi dan asas syariat adalah hukum dan kemaslahatan hamba dalam kehidupan dunia dan akhirat. Syariat membawa keadilan, rahmat, hikmah dan kemaslahatan bagi semuanya. ${ }^{10}$ Pernyataan tersebut menunjukkan bahwa kemaslahatan sebagai asas untuk mengubah fatwa hukum menurut perubahan waktu, tempat, keadaan, dan adat kebiasaan yang berlaku di suatu tempat sesuai dengan tujuan dan kemaslahatan yang diinginkan pembuat syariat ketika mensyariatkan suatu hukum. Oleh karena itu, syariat memberikan hukum yang berbeda untuk situasi kondisi dan aktivitas yang berbeda.

Landasan teori pemikiran Ibnu al-Qayyim al-Jauziyyah tentang perubahan hukum terhadap perkembangan sosial hukum Islam pada prinsipnya mengacu pada hakikat syariat Islam yang senantiasa berorientasi pada kemaslahatan manusia. Syariat Islam hadir di bumi melalui Rasulullah saw. yang bertujuan untuk mewujudkan keadilan hukum, kemaslahatan dan kebajikan. Oleh karena itu, setiap ketentuan atau aturan hukum yang tidak memenuhi asas keadilan, dipandang bertentangan dengan syariat Islam.

Ibnu al-Qayyim al-Jauziyyah dalam pemikiran hukumnya tersebut menegaskan bahwa hukum yang dipengaruhi oleh kelima faktor terebut adalah hukum yang disesuaikan dengan tuntutan kemaslahatan pada situasi waktu, tempat dan keadaan tertentu seperti ukuran, jenis dan sifat hukuman. Dalam kondisi ini, syariat memberikan kebebasan untuk memilih yang paling sesuai dengan kemaslahatannya. Adapun hukum yang baku dan tidak berubah karena zaman, tempat dan ijtihad ulama. Seperti perkara-perkara yang wajib dan haram, sanksi bagi tindak pidana yang telah 
192 | Diktum: Jurnal Syari'ah dan Hukum, Volume 16, Nomor 2 Desember 2018 : 187 - 207

ditetapkan oleh syariat dan lain-lain. diungkapkan melalui wawancara. Hukum seperti ini tidak mengalami Berikut ini dikemukakan beberapa perubahan dan tidak menyediakan wawancara dari hakim Peradilan ruang bagi ijtihad lain yang berbeda. ${ }^{11} \quad$ Agama terkait dengan pendapat hukum

Ibnu al-Qayyim al-Jauziyyah mengungkapkan bahwa dalam memahami nas harus dapat mengkomparasikan antara tujuan syariat dan tekstualitas dalam nas, agar pemahaman terhadap teks-teks keagamaan tidak secara parsial melainkan secara komprehensip. ${ }^{12}$ Pemikiran Ibnu al-Qayyim alJauziyyah tentang perubahan hukum terhadap perkembangan sosial hukum Islam menunjukkan bahwa syariat Islam bersifat fleksibel dan adaptif dalam merespon setiap perubahan dan perkembangan. Ibnu al-Qayyim alJauziyyah berpendapat bahwa hukum Islam dapat ditafsirkan dan diterjemahkan sesuai konteks sosial umat.

Pandangan hakim Peradilan Agama tentang perubahan hukum menurut Ibnu al-Qayyim al-Jauziyyah dalam memutuskan atau menetapkan perkara di lingkungan Peradilan Agama wilayah Sulawesi Selatan dapat Ibnu al-Qayyim al-Jauziyyah tentang perubahan hukum.

Arief Musi, hakim Pengadilan Agama Makassar mengemukakan bahwa hampir seluruh putusan dan penetapan hukum di Pengadilan Agama dipengaruhi oleh faktor alazman, wa al-makan, wa ahwal. Oleh karena itu, teori Ibnu al-Qayyim alJauziyyah ini sangat relevan, bahkan tidak sekadar relevan, tetapi hal itu merupakan aspek yang substansial, sangat urgent untuk diterapkan oleh setiap hakim yang akan memutus atau menetapkan perkara. Perubahanperubahan sosial itu sangat mempengaruhi perubahan hukum". ${ }^{13}$

Berdasarkan wawancara tersebut didapatkan keterangan bahwa pandangan hakim Peradilan Agama tentang teori perubahan hukum Ibnu al-Qayyim al-Jauziyyah terkait bagi hakim dalam memutuskan atau menetapkan perkara yang dihadapinya. 
Hal itu dibuktikan dengan ungkapan Arief Musi dalam wawancaranya bahwa pendapat hukum Ibnu alQayyim tersebut bukan saja releva, tetapi urgent bagi setiap hakim Peradilan Agama dalam memutuskan atau menetapkan suatu perkara yang diperhadapkan kepadanya.

Hal yang senada diungkapkan oleh Mame Sadafal, hakim Pengadilan Tinggi Agama (PTA) Makassar mengemukakan bahwa hukum berkembang tergantung situasi dan kondisi masyarakat setempat. Teori perubahan sosial Ibnu al-Qayyim alJauziyyah, pada dasarnya menyoroti keadaan masyarakatnya ketika itu, mereka tidak lagi berijtihad dalam memfatwakan hukum, tetapi mereka bertaklid kepada pendapat-pendapat ulama pendahulunya. ${ }^{14}$

Berdasarkan hasil wawancara tersebut didapatkan keterangan bahwa pandangan hakim Peradilan Agama tentang perubahan hukum menurut Ibnu al-Qayyim al-Jauziyyah sangat erat kaitannya ketika hakim memutuskan atau menetapkan suatu perkara hukum. Bahkan, Mame Sadafal lebih detail menguraikan teori Ibnu al-Qayyim tersebut bahwa inti dari pemikran Ibnu al-Qayyim tersebut adalah memerangi taklid yang sedang mewabah di masyarakat ketika itu dan berusaha membangkitkan kembali gairah ijtihad seperti yang terjadi pada zaman Rasulullah saw., zaman Sahabat dan zaman para imam mujtahid/ imam mazhab.

Gunawan, hakim Pengadilan Agama Parepare mengemukan bahwa ada 4 faktor yang mempengaruhi perubahan dalam teori perubahan hukum Ibnu al-Qayyim al-Jauziyyah yaitu waktu, tempat, keadaan dan niat. Contoh pembaharuan yang sesuai dengan teori Ibnu al-Qayyim alJauziyyah, di antaranya adalah persoalan harta bersama yang dikenal dengan istilah harta gono-gini. Kalau zaman dahulu seorang suami meninggal, dibagi warisan secara langsung. Akan tetapi, zaman sekarang linnisai nasibun mimmaktasabna, dalam artian masing-masing punya kewajiban. Perolehan itu tidak mesti ikut bekerja, jadi di rumah itu dihargai 
194 | Diktum: Jurnal Syari'ah dan Hukum, Volume 16, Nomor 2 Desember 2018 : 187 - 207

keringat seorang istri. Jadi, apapun yang dilakukan atau didapat oleh suami, maka istri juga dapat setengahnya. Pada dasarnya teori Ibnu al-Qayyim al-Jauziyyah ini tidak tersurat dipakai, akan tetapi secara tersirat tetap digunakan dalam memutuskan persoalan hukum. ${ }^{15}$

Berdasarkan hasil keterangan wawancara tersebut didapatkan keterangan bahwa teori perubahan sosial Ibnu al-Qayyim al-Jauziyyah ini secara tersurat memang tidak disebutkan, tetapi secara tersirat teori ini tetap dipakai seperti contoh-contoh yang akan dikemukan berikut ini.

\section{B. Kontekstualisasi Pemikiran Ibnu al-Qayyim al-Jauziyyah tentang Perubahan Hukum di Lingkungan Peradilan Agama Wilayah Sulawesi Selatan}

1. Analisis Putusan Nomor 73/Pdt.G/ 2013 PA. Pare dan Putusan Banding Nomor 55/Pdt.G/2013/ PTA Mks tentang Nafkah Idah.

Perkara pemberian nafkah idah, pada perkara cerai talak Putusan Nomor 73/Pdt.G/ 2013 PA. Pare dan Putusan Banding Nomor 55/Pdt.G/2013/ PTA Mks tentang
Nafkah Idah. Hal yang menjadi dasar pertimbangan Majelis Hakim ditetapkannya pemberian nafkah idah adalah asas kemanfaatan dan asas keadilan agar tidak memberatkan pihak suami dan tidak menzalimi pihak isteri.

Hasil wawancara dengan salah sorang hakim Pengadilan Agama Parepare Gunawan menyatakan bahwa salah satu pertimbangan hakim dalam putusan Nomor 73/Pdt.G/ 2013 PA. Pare adalah pemohon sudah pernah memberikan uang sebanyak 30 juta rupiah. Pemohon mengambil kredit di Bank BRI sebanyak Rp 60.000.000 (enam puluh juta) dan Rp 30.000.000,(tiga puluh juta) Pemohon berikan kepada termohon dengan perjanjian termohon tidak mempunyai hak dengan gaji Pemohon. Di samping itu pemohon atas kerelaannya sendiri memberikan sebuah rumah sebagai mut'ah untuk si termohon. Hal itu menjadi sebab si pemohon hanya memberikan nafkah idah sebanyak 600 ribu (enam ratus ribu rupiah), selama tiga bulan. ${ }^{16}$

$$
\text { Pertimbangan kesanggupan }
$$


pemohon tersebut majelis hakim Pengadilan Agama Parepare dapat mempertimbangkan bahwa kesanggupan pemohon tersebut dipandang layak dan patut bila pemohon dibebani untuk membayar nafkah idah dan mut'ah seperti yang disebutkan.

Perbedaan pertimbangan majelis hakim ditingkat banding Pengadilan Tinggi Agama Makassar yang menyatakan bahwa, termohon/ pembanding dalam hal pelayanan dan pengabdiannya sebagai istri dari pemohon/ terbanding selama perkawinannya yang hingga sekarang kurang lebih 23 tahun harus memperoleh keadilan. Oleh karena itu, hakim banding sependapat dan sangat menyetujui pertimbangan hakim pertama yang secara ex officio memberikan hak nafkah idah, tetapi hakim banding tidak sependapat mengenai besarnya sesuai kesanggupan pemohon dalam repliknya sebesar Rp.600.000,- (enam ratus ribu rupiah ) selama 3 bulan, karena dianggap tidak layak dan tidak patut apabila dibandingkan dengan biaya hidup sekarang sesuai dengan maksud disyariatkannya nafkah idah tersebut. Menurut hakim banding yang layak dan patut adalah sebesar $\mathrm{Rp}$. 1.000.000,-( satu juta rupiah ) setiap bulan sehingga berjumlah Rp. 3. 000. 000 ( tiga juta rupiah) selama 3 bulan.

Adapun mut'ah yang dibebankan oleh hakim tingkat pertama sesuai kesanggupan pemohon/ terbanding berupa 1 (satu) unit rumah. Hakim banding menyetujuinya karena telah sesuai pula dengan abstrak hukum dalam Yurisprudensi Mahkamah Agung RI Nomor 106 K/AG/1997 bahwa permohonan cerai tersebut diajukan oleh pemohon sebagai suami, dan dari fakta dalam persidangan tidak terbukti sebagai penyebab percekcokan rumah tangga tersebut murni dari termohon, oleh karena itu berdasar pasal 41 huruf (c) Undang-undang Nomor 1 Tahun 1974 jo pasal 149 Kompilasi Hukum Islam, pemohon diwajibkan untuk membayar nafkah idah dan mut'ah kepada termohon.

Hal ini juga yang dinyatakan oleh Dr. Mame, hakim Pengadilan 
196 | Diktum: Jurnal Syari'ah dan Hukum, Volume 16, Nomor 2 Desember 2018 : 187 - 207

Tinggi Agama Makassar bahwa salah satu pertimbangan hakim dalam memutuskan perkara nafkah idah setelah perceraian adalah pertimbangan sistem keadilan. Pasangan suami istri hidup berumah tangga selama berpuluh tahun dan berkonsentrasi mengurus rumah tangganya, kehidupan berawal dari nol, hingga akhirnya suaminya sukses dalam kariernya, kemudian suami menceraikan istrinya. Kasus seperti ini si istri harus memperoleh keadilan dengan memberikan nafkah idah dan mut'ah yang layak. ${ }^{17}$

\section{Berdasarkan pemaparan}

tersebut, dapat dikemukakan bahwa hal yang paling penting dalam memutuskan perkara nafkah idah adalah dengan memperhatikan tujuan dan dasar hukum tersebut, yakni asas keadilan, kemamfaatan dan kepastian hukum. Dari segi asas keadilan hukum, harus dipertimbangkan kedudukan istri sebagai menager dalam rumah tangga, meskipun pada dasranya tidak terlibat dalam hal mencari nafkah, tetapi segala urusan domestik rumah tangga istri bertangung jawab. Oleh sebab itu, suatu ketidakadilan apabila terjadi suatu perceraian yang bukan murni kesalahan dari si istri. Isteri tidak mendapat nafkah idah atau mendapatkan, tetapi tidak sepantasnya yang dia dapatkan. Dalam hal ini alQur'an sudah memberikan solusi bahwa nafkah idah setelah terjadi perceraian diberikan suami kepada istri selama dalam masa idah dengan ukuran sesuai dengan kemampuan dan kesanggupan sang suami tersebut. Oleh karena itu, yang lebih tepat adalah pemenuhan kebutuhan (makan, pakaian dan tempat tinggal), bagi istri harus disesuaikan dengan perkembangan zaman dan kebiasaan setempat.

Dengan demikian, putusan hakim Pengadilan Tinggi Agama Makassar yang menyatakan pemberian nafkah idah pemohon/ terbanding kepada termohon/ pembanding dalam repliknya sebesar Rp.600.000,- (enam ratus ribu rupiah ) selama 3 bulan, dianggap tidak layak dan tidak patut apabila dibandingkan dengan biaya hidup sekarang sesuai dengan maksud disyariatkannya nafkah idah tersebut. 
Menurut hakim banding yang layak dan patut adalah sebesar Rp. 1.000.000,-(satu juta rupiah) setiap bulan sehingga berjumlah Rp. 3000.000 ( tiga juta rupiah) selama 3 bulan. Putusan hakim banding PTA Makasar tersebut sudah sejalan dengan pemikiran hukum Ibnu Qayyim alJauziyyah yang menyatakan bahwa perubahan dan perbedaan fatwa berdasarkan perubahan waktu, tempat, kondisi dan niat serta adat. Pemenuhan kebutuhan nafkah idah berupa (papan, sandan dan pangan), bagi istri yang ditalak rujuk harus disesuaikan dengan perkembangan zaman dan kebiasaan setempat, selain kemampuan suaminya.

\section{Analisis Putusan Nomor 2414/Pdt.G/2017/PA Mks tentang Sita Jaminan Harta Bersama.}

Perkara sita jaminan harta bersama putusan Nomor 2414/Pdt.G/2017/PA Mks, pokok sengketa dalam gugatan ini adalah penggugat bermaksud agar harta bersama dalam perkawinan disita oleh
Pengadilan Agama Makassar karena ada sangkaan tergugat akan mengalihkan harta bersama tersebut, terutama saat ini penggugat dengan tergugat sudah tidak harmonis lagi. Oleh karena itu, penggugat mengajukan permohonan kepada Pengadilan Agama Makassar agar meletakkan sita jaminan, yang muatannya tidak mengandung sengketa (disputes) maupun pelaksanaan pembagian harta bersama.

Ada beberapa hal yang menjadi dasar pertimbangan majelis hakim dalam memutuskan perkara sita jaminan harta bersama putusan Nomor 2414/Pdt.G/2017/PA Mks, dasar pertimbangan yang dimaksud adalah:

1. Tergugat merasa keberatan kalau objek sita tersebut dinyatakan berstatus harta bersama, karena penggugat tidak punya andil sedikitpun atas pembelian maupun pengadaannya.

Sangkaan tergugat bahwa sebagai kepala rumah tangga berhak untuk mengalihkan harta tersebut karena objek bermaksud untuk dibeli atau diadakan oleh tergugat tanpa 
198 | Diktum: Jurnal Syari'ah dan Hukum, Volume 16, Nomor 2 Desember 2018 : 187 - 207

adanya andil dari penggugat. Objek yang dimintakan sita jaminan adalah dibeli atas gaji tergugat sebagai PNS, maka merupakan hak tergugat sebagai kepala rumah tangga untuk melakukan perbuatan hukum antara lain tergugat berhak untuk mengalihkan barang milik Tergugat tersebut.

Majelis Hakim Pengadilan Agama Makassar berpendapat bahwa tidak tepat dalil tergugat yang menyatakan objek yang dimintakan sita jaminan bukan berstatus sebagai harta bersama, karena penggugat tidak punya andil dalam pengadaannya. Berdasarkan hukum, harta yang terkumpul dalam perkawinan selain yang ditentukan menurut ketentuan Pasal 35 ayat (2) Undang-undang Nomor 1 Tahun 1974 tentang Perkawinan adalah berstatus sebagai harta bersama, tanpa mempersoalkan terdaftar atas nama siapa.

Hasil wawancara dengan H. A. Majid Jalaluddin, hakim Pengadilan Agama Makassar menyatakan bahwa harta gono-gini adalah harta syarikah/ bersama suami istri tanpa mempersoalkan yang mengadakannya". ${ }^{18}$

Abdul Manan menyatakan bahwa harta bersama merupakan harta perkawinan yang dimiliki suami istri secara bersama-sama, baik harta bergerak maupun tidak bergerak yang diperoleh sejak terjalinnya hubungan suami istri yang sah, yang dapat dipergunakan oleh suami dan istri untuk membiayai keperluan hidup mereka beserta anak-anaknya, sebagai satu kesatuan yang utuh dalam rumah tangga. Oleh karena itu, harta bersama adalah harta yang diperoleh selama ikatan perkawinan berlangsung dan tanpa mempersoalkan terdaftar atas nama dari salah satu keduanya. ${ }^{19}$

Semua pendapatan atau penghasilan suami istri selama ikatan perkawinan, selain harta asal dan/atau harta pemberian yang mengikuti harta asal adalah harta bersama. Istri tidak menjadi masalah jika ikut aktif bekerja atau tidak, walaupun istri hanya tinggal di rumah mengurus rumah tangga dan anak, sedangkan yang bekerja suami sendiri. ${ }^{20}$ Hal ini sesuai dengan putusan Mahkamah Agung tanggal 7 $\begin{array}{lll}\text { September } & 1956 \quad \text { No. }\end{array}$ 
51/K/Sip/1956, bahwa menurut hukum adat, semua harta yang diperolehkan selama berlangsungnya perkawinan termasuk dalam gono gini, meskipun mungkin hasil kegiatan suami sendiri. $^{21}$

Berdasarkan ketentuan Pasal 35 dan 36 di atas, maka Undang-undang Nomor 1 Tahun 1974 tidak menganut asas percampuran atau penyatuan harta akibat adanya perkawinan. Harta bawaan, hadiah dan warisan suami dan istri terpisah dan tetap di bawah penguasaan masing-masing dan merupakan hak sepenuhnya, sepanjang para pihak tidak menentukan lain melalui perjanjian perkawinan. Harta bersama yang diperoleh selama dalam ikatan perkawinan, menjadi milik bersama suami istri, tanpa mempersoalkan yang menguras jerih payahnya untuk memperoleh harta tersebut serta dikuasai dan dikelola secara bersama dan masingmasing suami istri merupakan pemilik bersama atas harta bersama tersebut.
2. Tergugat terbukti telah menjual satu unit sepeda motor tanpa sepengetahuan penggugat;

Penjualan sepeda motor yang dilakukan oleh tergugat tidak sepengetahuan penggugat, dan penjualan itu dilakukan oleh tergugat karena memandang remeh kedudukan penggugat sebagai istri. Tergugat sering mengatakan kalau gajinya sebagai Pegawai Negeri Sipil yang digunakan membeli barang-barang yang ada. Selain telah menjual sepeda motor, penggugat juga mendengar berita tergugat akan menjual rumah harta bersama.

Salah satu pertimbangan Majelis Hakim Pengadilan Agama Makassar bahwa untuk meminta sita jaminan atas harta bersama sebagaimana tersebut dalam dalil-dalil gugatan, penggugat cukup mempunyai alasan antara lain tergugat terbukti telah menjual satu unit sepeda motor tanpa sepengetahuan penggugat; Menimbang, bahwa menurut Pasal 92 Kompilasi Hukum Islam suami atau isteri tanpa persetujuan pihak lain tidak 
diperbolehkan menjual atau memindahkan harta bersama.

Keberadaan harta bersama dalam perkawinan semata-mata ditujukan untuk memenuhi kebutuhan suami dan istri secara bersama-sama beserta anak-anak mereka, sehingga penggunaan harta bersama harus atas persetujuan bersama suami dan istri, tidak boleh dikuasai secara sepihak dan semena-mena. Oleh karena itu, jik ada persangkaan atau terindikasi adanya tindakan penyalahgunaan oleh salah satu pihak di antara suami atau istri, dengan memindahtangankan kepada pihak lain, memboroskan atau menggelapkan atas harta bersama tersebut, maka undang-undang memberikan jaminan agar keutuhan harta bersama dalam perkawinan itu tetap terlindungi dan terjaga melalui upaya "penyitaan" atas permohonan yang diajukan pihak suami atau istri serta pihak yang berkepentingan kepada pengadilan. ${ }^{22}$

Respon terhadap dinamika perkembangan hukum yang hidup dalam masyarakat tersebut, maka masalah sita harta bersama dalam perkawinan di luar sengketa perceraian secara tegas termaktub dalam Kompilasi Hukum Islam, Pasal 95 menyatakan, bahwa:

"(1) Dengan tidak mengurangi ketentuan Pasal 24 ayat (2) huruf c Peraturan Pemerintah No. 9 Tahun 1975 dan Pasal 136 ayat (2), suami atau istri dapat meminta Pengadilan Agama untuk meletakkan sita jaminan atas harta bersama tanpa adanya permohonan gugatan cerai, apabila salah satu melakukan perbuatan yang merugikan dan membahayakan harta bersama seperti judi, mabuk, boros, dan sebagainya. (2) Selama masa sita dapat dilakukan penjualan atas harta bersama untuk kepentingan keluarga dengan izin Pengadilan Agama."23

Pasal 136 ayat 2 Kompilasi

Hukum Islam menyatakan, bahwa:

"Selama berlangsungnya gugatan perceraian, atas permohonan penggugat atau tergugat, Pengadilan Agama dapat:

a. Menentukan nafkah yang harus ditanggung oleh suami.

b. Menentukan hal-hal yang perlu untuk menjamin terpeliharanya barangbarang yang menjadi hak bersama suami-istri atau barang-barang yang menjadi hak suami atau barang-barang yang menjadi hak istri.",24

Adapun yang dimaksud dalam Peraturan Pemerintah No. 9 Tahun 
1975 Pasal 24 ayat (2) huruf c adalah:

"Menentukan hal-hal yang perlu untuk menjamin terpeliharanya barang-barang yang menjadi hak bersama suami-istri atau barangbarang yang menjadi hak suami atau barang-barang yang menjadi hak istri.'

Pasal 91 KHI juga menentukan tentang bentuk kekayaan bersama, yaitu;

"(1) harta bersama sebagaimana tersebutdalam pasal 85 dapat berupa benda berwujud atau tidak berwujud; (2) harta benda berwujud dapat meliputi benda yang tidak bergerak, benda bergerak, dan surat-surat berharga; (3) harta benda tidak berwujud dapat berupa hak maupun kewajiban; dan (4) harta bersama dapat dijadikan sebagai barang jaminan oleh salah satu pihak atas persetujuan pihak lainnya".

Hal yang perlu dicatat lagi bahwa KHI (Pasal 95 tersebut) telah mengantisipasi apabila salah satu pihak (suami atau istri) pemborosan; judi, mabuk, dan lain-lain yang merugikan dan membahayakan serta dikhawatirkan memindahtangankan pih ak ketiga harta bersama tersebut. Dengan demikian, pihak suami atau istri dapat meminta Pengadilan Agama untuk melakukan sita harta bersama tanpa adanya permohonan cerai.
Selama masa sita tersebut dapat dilakukan penjualan harta bersama untuk kepentingan keluarga, rumah tangga, istri dan anak-anaknya. Hakim memiliki otoritas untuk menangani dan menjaga agar harta tersebut dengan meletakkan sita harta bersama. Selain itu, otoritas yang diberikan kepada hakim adalah untuk mengendalikan atau setidak-tidaknya mengurangi kebiasaan suami atau istri melakukan perbuatan yang tidak disukai oleh syariat Islam.

Berdasarkan data yang ada dan analisis yang dilakukan terhadap putusan-putusan yang dihasilkan oleh hakim di di Lingkungan Peradilan Agama Wilayah Sulawesi Selatan. Ada dua karakteristik putusan-putusan yang dilahirkan oleh hakim-hakim Peradilan Agama di lingkungan Peradilan Agama Sulawesi Selatan. Karakteristik tersebut adalah:

Pertama, hakim-hakim di lingkungan Peradilan Agama Wilayah Sulawesi Selatan berperan menerapkan yang telah diatur dalam peraturan perundang-undangan dan Kompilasi Hukum Islam. Dalam hal ini, hakim 
202 | Diktum: Jurnal Syari'ah dan Hukum, Volume 16, Nomor 2 Desember 2018 : 187 - 207

Peradilan Agama berperan sebagai corong undang-undang. Seperti yang terjadi dalam kasus putusan hukum Nomor 2414/Pdt.G/2017/PA Mks tentang sita jaminan harta bersama. Hakim memutus hukum hanya berdasar kepada pasal-pasal yang tertera dalam undang-undang, dan Kompilasi Hukum Islam (KHI). Hal ini disebabkan oleh aturan hukum tersebut sudah jelas dan tidak membutuhkan tafsiran lagi. Hal ini sesui dengan yang dikatakan Ibnu al-Qayyim al-Jauziyyah bahwa dalam hal hukumnya sudah jelas seperti perkara-perkara yang wajib dan haram yang secara qat'i telah ditetapkan oleh syariat, maka hukum tersebut tidak mengalami perubahan dan tidak menyediakan ruang bagi ijtihad lain yang berbeda. Dalam arti bahwa yang tertera dalam teks-teks peraturan perundangundangan diterapkan sesuai teksnya dan tidak diperkenangkan memberi interpretasi atau penafsiran yang lain.

Kedua, hakim memutuskan perkara dalam kasus yang hukumnya tidak jelas. Hakim akan menafsirkan hukum atau undang-undang. Hal ini seperti tergambar dalam kasus putusan hakim Nomor 73/Pdt.G/ 2013 PA. Pare dan Putusan Banding Nomor 55/Pdt.G/2013/ PTA Mks tentang Nafkah Idah. Hal yang menjadi dasar pertimbangan Majelis Hakim ditetapkannya pemberian nafkah idah adalah asas kemanfaatan dan asas keadilan agar tidak memberatkan pihak suami dan tidak menzalimi pihak istri. Hakim dalam putusannya memberikan nafkah idah sebesar 600 ribu (enam ratus ribu rupiah) selama tiga bulan atau 200 ribu perbulan.

Hal yang lain terjadi dengan pertimbangan Majelis Hakim di tingkat banding Pengadilan Tinggi Agama Makassar yang menyatakan bahwa namun demikian termohon/ pembanding dalam hal pelayanan dan pengabdiannya sebagai istri dari pemohon/ terbanding selama perkawinannya yang hingga sekarang kurang lebih 23 tahun harus memperoleh keadilan. Oleh karena itu, hakim banding tidak sependapat mengenai besarnya sesuai kesanggupan pemohon dalam 
repliknya sebesar Rp. 600.000,- (enam ratus ribu rupiah ) selama 3 bulan, karena dianggap tidak layak dan tidak patut apabila dibandingkan dengan biaya hidup sekarang sesuai dengan maksud disyariatkannya nafkah idah tersebut, sehingga menurut hakim banding yang layak dan patut adalah sebesar Rp. 1.000.000,-( satu juta rupiah) setiap bulan sehingga berjumlah Rp. 3. 000.000 ( tiga juta rupiah) selama 3 bulan.

Berdasarkan pemaparan tersebut, dapat dikemukakan bahwa hal yang paling penting dalam memutuskan perkara nafkah idah adalah dengan memperhatikan tujuan dan asas hukum tersebut, yakni asas keadilan, kemanfaatan dan kepastian hukum. Dari segi asas keadilan hukum, harus dipertimbangkan kedudukan istri sebagai menager dalam rumah tangga, meskipun pada dasarnya tidak terlibat mencari nafkah, tetapi segala urusan domestik rumah tangga istri bertangung jawab. Oleh sebab itu, suatu ketidakadilan jika terjadi suatu perceraian yang bukan murni kesalahan dari istri dan tidak mendapat nafkah idah atau mendapatkan, tetapi tidak sepantasnya yang didapatkan. Dalam keadaan seperti ini, istri harus memperoleh keadilan dengan diberikan nafkah idah dan mut'ah yang layak. Oleh sebab itu, yang lebih tepat adalah pemenuhan kebutuhan (makan, pakaian dan tempat tinggal), bagi istri harus disesuaikan dengan perkembangan zaman dan kebiasaan setempat, selain kemampuan suaminya.

Terkait dengan teori Ibnu Qayyim al-Jauziyyah yang menegaskan bahwa faktor yang terpenting untuk merumuskan ketentuan hukum, atau penetapan hukum harus dikaitkan dengan lima hal yakni: al-azmina (situasi zaman), alamkinah (situasi tempat), al- ahwāl (kondisi) al-niyāt (motivasi/ niat), dan al-awāid (adat-tradisi). Semua keadaan tersebut mempengaruhi adanya pengembangan hukum. Suatu ketetapan hukum telah ada pada masa lalu, namun karena masa dan situasi sekarang berbeda dengan yang lalu, maka hukum itu berubah untuk lebih dikembangkan. Dalam kasus yang 
204 | Diktum: Jurnal Syari'ah dan Hukum, Volume 16, Nomor 2 Desember 2018 : 187 - 207

sama akan tetapi $a h\} w a>l$ atau kondisi yang bersangkutan berbeda, maka penerapan hukumnya juga berbeda.

Landasan teori pemikiran Ibnu al-Qayyim al-Jauziyah tentang perubahan hukum terhadap perkembangan sosial hukum Islam pada prinsipnya mengacu pada hakikat syariat Islam yang senantiasa berorientasi pada kemaslahatan manusia. Syariat hadir di bumi melalui Rasulullah bertujuan untuk mewujudkan keadilan hukum, kemaslahatan dan kebajikan. Oleh karena itu, segala ketentuan atau aturan hukum yang tidak memenuhi asas keadilan, dipandang bertentangan dengan syariat Islam.

\section{PENUTUP}

Berdasarkan pembahasan

tersebut, ditarik beberapa kesimpulan sebagai berikut:

1. Pandangan hakim Peradilan Agama tentang perubahan hukum menurut Ibnu alQayyim al-Jauziyah sangat terkait pada saat hakim memutuskan atau menetapkan suatu perkara, pemikiran hukum Ibnu al-Qayyim secara tidak langsung diterapkan di lingkungan Peradilan Agama. Inti dari pemikiran hukum Ibnu al-Qayyim bahwa faktor yang terpenting untuk merumuskan ketentuan hukum adalah dikaitkan dengan lima hal yakni: al-azmina (situasi zaman), al-amkinah (situasi tempat), al-ah\}wa>l (kondisi) al-niyāt (motivasi/ niat), dan al'awāid (adat-tradisi). Kelima faktor inilah yang menjadi sebab (al-illah) dalam perubahan fatwa hukum. Pendapat hukum Ibnu alQayyim tersebut sangat urgent diterapkan bagi setiap hakim Peradilan Agama dalam memutuskan atau menetapkan suatu perkara yang diperhadapkan kepadanya. Hakim ketika memutuskan perkara melihat dengan situasi dan kondisi masyarakat setempat, sebagaimana beberapa contoh putusan dan 
Rusdaya Basri, Urgensi Pemikiran Ibnu Qayyim al-Jauziyyah................................. | 205

penetapan hukum hakim yang telah dikemukakan.

2. Pemikiran Ibnu al-Qayyim alJauziyyah tentang perubahan hukum terhadap perkembangan sosial hukum Islam sebagian sudah terkontekstualisasi di lingkungan Peradilan Agama wilayah Sulawesi Selatan. Hal ini terlihat pada penetapan hukum tentang putusan banding Nomor 55/Pdt.G/2013/ PTA Mks tentang Nafkah Idah yang menolak putusan hukum Nomor 73/Pdt.G/ 2013 PA. Pare. Dan kasus putusan hukum Nomor 2414/Pdt.G/2017/PA Mks tentang sita jaminan harta bersama. 


\section{DAFTAR PUSTAKA}

\section{Bibliograpy}

Imam Muslim, Sahih Muslim, dalam Bab Isti'żān al-Nabi saw. Rabbahu 'an Ziyarati al- Qabri. Juz. 5, \{CD. ROOM, Maktabah Syamilah\}.

Madjid, Nurcholish. Islam; Doktrin dan Peradaban (Jakarta: Yayasan Wakaf Paramadina, 1995).

al-Sayis, Muhammad 'Ali Tarīkh alFiqh al-Islāmi (Al- Qāhirah: Maktabah Muhammad 'Ali Șubaih wa aulādih,t.th).

al-Qardawi, Al-Imam Yusuf. AlSiyasah al-Syar iyyah fi Daui Nusus al-Syari'ati wa Maqasiduha, Cet. IV; alQahirah: Maktabah Wahbah, 2011.

Mubarak, Jaih. Modifikasi Hukum Islam: Studi tentang Qaul alQadim dan Qaul al-Jadid (Cet. I; Jakarta: RajaGrafindo Persada, 2002.

al-Jauziyyah, Ibnu al-Qayyim 'Ilām alMuwaqqi in an Rabbi al'Álamin, Juz. 3. Cet. I; alQāhirah: Dār al- Hadis̀, 1993.

Arrasyid, Chainur Dasar-Dasar Ilmu Hukum. Cet. I; Jakarta: Sinar Grafika, 2000.

Rivai, Ahmad. Penemuan Hukum oleh Hakim dalam Perspektif Hukum Progresif. Cet. III; Jakarta: Sinar Grafika, 2014.

al-Qardawi, Al-Imam Yusuf. Madkhal liDirāsah al-Syari'ah alIslāmiyah. Cet. VI; al-Qahirah: Maktabah Wahbah, 2009.

Manan, Abdul "Beberapa Masalah tentang Harta Bersama", Mimbar
Hukum, No. XXX, Tahun 1997, h. 59.

Hadikusuma, Hilman. Hukum Waris Adat. Cet. VII; Bandung: PT. Citra Aditya Bakti, 2003.

al-Shadiq, Mukhtar Sita Harta Bersama Tanpa Adanya Sengketa Perkawinan dalam Hukum Perkawinan Indonesia. http://mukhtar-

nur.blogspot.co.id/2012/09/sitaharta-bersama-dalamhukum.html. (diakses pada tanggal 1 Februari 2018).

Mahkamah Agung RI, Kompilasi Hukum Islam (Direktorat Jenderal Badan Peradilan Agama, 2015), h. 51.

Mahkamah Agung RI, Himpunan Peraturan Perundang-undangan di Lingkungan Peradilan Agama, h. 832 .

Rusdi, Muhammad Ali. "Maslahat sebagai Metode Ijtihad dan Tujuan Utama Hukum Islam." DIKTUM: Jurnal Syariah dan Hukum 15.2 (2017): 151-168. 


\section{Catatan Akhir}

${ }^{1}$ Artinya: "Dari 'Abdullah bin Buraedah dari bapaknya berkata: Rasulullah saw. bersabda saya dulu melarang kamu berziarah kubur, maka sekarang berziarah kuburlah kalian”. Imam Muslim, Șahih Muslim, dalam Bab Isti'żān al-Nabi saw. Rabbahu 'an Ziyarati al- Qabri. Juz. 5, \{CD. ROOM, Maktabah Syamilah\}, h. 107.

${ }^{2}$ Nurcholish Madjid, Islam; Doktrin dan Peradaban (Jakarta: Yayasan Wakaf Paramadina, 1995), h. 392.

${ }^{3}$ Muhammad 'Ali al-Sayis, Tarīkh alFiqh al-Islāmi (Al- Qāhirah: Maktabah Muhammad 'Ali Șubaih wa aulādih,t.th), h.45.

${ }^{4}$ Lihat Al-Imam Yusuf al-Qardawi, Al-Siyasah al-Syar'iyyah fi Daui Nusus alSyari'ati wa Maqasiduha, (Cet. IV; alQahirah: Maktabah Wahbah, 2011), h. 235236.

${ }^{5}$ Jaih Mubarak, Modifikasi Hukum Islam: Studi tentang Qaul al-Qadim dan Qaul al-Jadid (Cet. I; Jakarta: RajaGrafindo Persada, 2002), h. 162. Lihat Muhammad Ali Rusdi,. "Maslahat sebagai Metode Ijtihad dan Tujuan Utama Hukum Islam." DIKTUM: Jurnal Syariah dan Hukum 15.2 (2017): 151-168.

${ }^{6}$ Lihat Ibnu al-Qayyim al-Jauziyyah, 'Ilām al-Muwaqqi 'in an Rabbi al-'Ālamin, Juz. 3 (Cet. I; al- Qāhirah: Dār al- Hadis̀, 1993), h. 5.

${ }^{7}$ Lihat Chainur Arrasyid, Dasar-Dasar Ilmu Hukum (Cet. I; Jakarta: Sinar Grafika, 2000), h. 74 .

${ }^{8}$ Ahmad Rivai, Penemuan Hukum oleh Hakim dalam Perspektif Hukum Progresif (Cet. III; Jakarta: Sinar Grafika, 2014), h. 14.

${ }^{9}$ Ibnu al-Qayyim al-Jauziyyah, 'Ilam al-Muwaqq in 'an Rabbi al-'Alamin... Juz. 3, (Cet. I; al-Qahirah: Dar al- Hadis, 1414 H/1993 M), h. 5.

${ }^{10}$ Ibnu al-Qayyim al-Jauziyyah, 'Ilām al-Muwaqqi 'in 'an Rabbi al-'Alamin, Juz. 3, h. 5 .

${ }^{11}$ Al-Imam Yusuf al-Qardawi, Madkhal liDirāsah al-Syari'ah al-Islāmiyah,
(Cet. VI; al-Qahirah: Maktabah Wahbah, 2009), h. 201-202.

${ }^{12}$ Ibnu al-Qayyim al-Jauziyyah, ' Ilām al-Muwaqqi 'i $n$.... Juz. 1, h. 197.

${ }^{13}$ Arief Musi (65 tahun), Hakim Pengadilan Agama (PA) Kelas IA Makassar, Wawancara, Makassar, 03 November 2017.

${ }^{14}$ Mame Sadafal (56 tahun), Hakim Pengadilan Tinggi Agama (PTA) Makassar, Wawancara, Makassar, 24 November 2017.

${ }^{15}$ Gunawan (50 tahun), Hakim Pengadilan Agama (PA) Kelas IB Parepare, Wawancara, Parepare, 26 Oktober 2017.

${ }^{16}$ Gunawan (50 tahun), Hakim Pengadilan Agama (PA) Parepare, Wawancara, Parepare 26 Oktober 2017.

${ }^{17}$ Mame Sadafal (56 tahun), Hakim Pengadilan Tinggi Agama (PTA) Makassar, Wawancara, Makassar, 24 November 2017.

${ }^{18}$ H. A. Majid Jalaluddin (63 tahun), Hakim Pengadilan Agama (PA) Kelas 1 Makassar, Wawancara, Makassar, 03 November 2017.

${ }^{19}$ Abdul Manan, "Beberapa Masalah tentang Harta Bersama", Mimbar Hukum, No. XXX, Tahun 1997, h. 59.

${ }^{20}$ Hilman Hadikusuma, Hukum Waris Adat (Cet. VII; Bandung: PT. Citra Aditya Bakti, 2003), h. 60.

${ }^{21}$ Putusan Mahkamah Agung tanggal 7 September 1956 No. 51/K/Sip/1956

${ }^{22}$ Mukhtar al-Shadiq, Sita Harta Bersama Tanpa Adanya Sengketa Perkawinan dalam Hukum Perkawinan Indonesia. http://mukhtar-nur.blogspot.co.id/2012/09/sitaharta-bersama-dalam-hukum.html. (diakses pada tanggal 1 Februari 2018).

${ }^{23}$ Mahkamah Agung RI, Kompilasi Hukum Islam (Direktorat Jenderal Badan Peradilan Agama, 2015), h. 51.

${ }^{24}$ Mahkamah Agung RI, Kompilasi Hukum Islam (Direktorat Jenderal Badan Peradilan Agama, 2015), h. 65.

${ }^{25}$ Mahkamah Agung RI, Himpunan

Peraturan Perundang-undangan di Lingkungan Peradilan Agama, h. 832. 